\title{
Article \\ Between Potential, Performance and Prospect: Revisiting the Political Leadership of the EU Commission President
}

\author{
Henriette Müller \\ NYUAD Institute, New York University Abu Dhabi, P.O. Box 129188, Abu Dhabi, United Arab Emirates; \\ E-Mail: henriette.mueller@nyu.edu
}

Submitted: 2 February 2016 | Accepted: 25 May 2016 | Published: 23 June 2016

\begin{abstract}
This contribution argues that although the latest EU treaties formalized the Commission presidency to substantial degree, it remains a constitutionally weak office for the provision of political leadership. The capacity to lead thus still strongly depends on the individual incumbent. As a first step, the article examines the legal-procedural structure of the office before and after the Lisbon Treaty came into force. Secondly, it analyzes the political leadership performance of the Commission president José Barroso in comparison with his predecessor Jacques Delors. In bridging formal institutional rules with concrete performances this article contributes to the understanding of the relationship between structure and agency in international institutions as well as to the growing literature on political leadership in the European Union.
\end{abstract}

\section{Keywords}

Barroso; Delors; EU Commission president; Lisbon Treaty; performance; political leadership

\section{Issue}

This article is part of the issue "New Approaches to Political Leadership", edited by Mark Bennister (Canterbury Christ Church University, UK).

(C) 2016 by the author; licensee Cogitatio (Lisbon, Portugal). This article is licensed under a Creative Commons Attribution 4.0 International License (CC BY).

\section{Introduction}

The president of the European Commission has always played a key role in the political system of the European Union (EU) and the larger process of European integration (Spence, 2006, p. 27). However, while "the incumbent is not able to fulfill the manifold functions attributed to him without exercising political leadership, [the institutional structure of the, H.M.] presidency is not designed to exercise such leadership" (Drake, 2000, p. 11; Kassim, 2013a, p. 1; Kassim et al., 2013, pp. 156, 160, 178; Tömmel, 2013, p. 789). In fact, it has ever since been an institutionally weak office. Nonetheless, scholars have observed a "strengthening of the Presidency since 2005" especially inside the Commission and that "the powers of the presidency have...come to match the importance of the office" (Kassim, 2013a, p. 3; Kassim, 2013b, p. 1; Kassim et al., 2013, p. 152). The presidency thus seems to be more powerful institutionally than ever before in European integration. In both acknowledging and qualifying this academic enthusiasm, the paper's aims are twofold.

First, it determines to what extent the institutional position of the office did actually change after the latest EU Treaty, namely the Lisbon Treaty of 2009. In this regard, the analysis reveals that the office's strong formalization inside the Commission had only very limited effects on the office's political power vis-à-vis other EU institutions, but was in fact an attempt to bring the office in line with increased institutional constraints. As a second step, the paper substantiates this claim by analyzing the leadership performance of José Barroso in comparison to his famous predecessor Jacques Delors through one of the office's key demands, the provision of public leadership in the European public spheres. The paper draws on theories of politicization of international organizations, which assume that the public visibility of an office increases alongside its institutional strengthening. Its analysis demonstrates that the office's latest formalization did not substantially increase the presi- 
dent's political role and authority at the European level (De Wilde \& Zürn, 2012, pp. 149-150; Rauh \& Zürn, 2014, p. 126; Zürn, 2013, pp. 19, 32).

\section{The European Commission Presidency: What Kind of Leadership Potential?}

Political leadership "is an essentially inter-personal process...between the leader (or leaders) and a set of followers within a particular group context", in which the leader obtains greater attention and influence, but only if followers let them do so (Ahlquist \& Levi, 2011, p. 5; Elgie, 2015, p. 26; Keohane, 2010, p. 53). Understood as this reciprocal-dynamic interaction, then, political leadership in executive offices does not only depend on the institutional structure of the office (positional leadership), but equally involves the incumbent's agency to lead (behavioral leadership) (Elgie, 2015, p. 27; Helms, 2005, pp. 19-20; Helms, 2016, p. 6). Regarding this agency-structure duality, scholars argued that "the more the power is concentrated in the hands of an individual leader (structure), the greater the influence of that leader's personality and preferences (agency)" (Byman \& Pollack, 2001, p. 140; Elgie, 1995, p. 204).

However, the opposite is also equally true. Applying the agency-structure duality to the supranational level of the European Union, this article argues that the weaker the institutional structure of an office, here the Commission presidency, the more the provision of political leadership by its incumbents depends on their personal agency. In this sense, the argument does not simply "recogniz[e] the importance of individuals" in international relations, but paradoxically still holds them paramount when it comes to political leadership in the European Union (Byman \& Pollack, 2001, p. 145; Helms, 2016, p. 5; Ross, 1995, p. 27; Spence, 2006, p. 27).

\subsection{Presidential Leadership Functions}

In accordance with the EU Commission's main functions (EUR-Lex, 2007, Art. 9 D/1), its president aims to fulfill three concrete leadership demands: agendasetting leadership, mediative-institutional leadership and public leadership (Cini, 1996, pp. 36-37; Curtin, 2009, pp. 62-63; Endo, 1999, pp. 26, 63-64; Tömmel, 2013, p. 790; Wille, 2013, pp. 61, 64; Kassim et al., 2013, p. 164; Peterson, 1999, p. 48). Combining these three distinct functions, active political leadership in supranational organizations is understood as the capacity "to attempt and succeed in going beyond institutional constraints, thereby expanding and creating resources and opportunities" in order to influence and achieve mutually desired, publicly supported political goals over a certain period of time (Endo, 1999, pp. 26, 28; Greenstein, 1992, p. 109; Tömmel, 2013, p. 790; Peterson, 1999, p. 48). Successful Commission presi- dents thus strategically transfer political ambitions of Pan-European scope into consensual agendas (agendasetting leadership). These can then be effectively mediated through the intra- and inter-institutional arenas of decision-making at the European level (meditativeinstitutional leadership) and gain support among European public spheres (public leadership).

According to the Rome Treaty, the Commission "shall promote the general interest of the Union and take appropriate initiatives to that end" (EUR-Lex, 1957, Art. 155; EUR-Lex, 2007, Art. 9 D/1). As its first representative, the Commission president has here always sought to provide political guidance and formulate the strategic goals of the Commission and the union more broadly (Curtin, 2009, p. 91; Peterson, 1999, p. 47). Political agenda-setting means to make choices "over the relative salience of individual dossiers, judgments as to their relative merits, efforts to get proposals into a shape in which they can be negotiated and...assess[ed] of their acceptability by the Council [and the Parliament, H.M.]" (Curtin, 2009, p. 74; Pollack, 1997, p. 102; Princen, 2009, p. 19). In seeking to ensure "policy expertise and institutional persistence", Commission presidents strategically invest in and prioritize the political agendas of the Commission in conjunction with the College of Commissioners, the European Council and Parliament more broadly (Kassim, 2013a, p. 14; Peterson, 1999, p. 48; Pollack, 1997, pp. $102,121)$. While the Rome Treaty left many "unknown or 'grey' areas", much depended on the presidents and their College "to prioritize the issues and thus clarify the future agendas of the Community" (Endo, 1999, p. 38).

The Amsterdam and Nice Treaties assigned this agenda-setting function to the president in a more official fashion: "The Commission shall work under the political guidance of its president..." (EUR-Lex, 1992/2002, Art. 219/217). Taking into account the Commission's right of initiative within the EU institutional framework, the treaties clearly enhanced the president's potential to set political agendas and provide "policy leadership" (Kassim, Connolly, Dehousse, Rozenberg, \& Bendjaballah, 2016, p. 7). However, while the Lisbon Treaty reinvigorated the president's pre-eminence vis-à-vis commissioners, it left out the small but significant word "political". It states: "The President shall lay down guidelines within which the Commission is to work" (EUR-Lex, 2007, Art. 9D/6(a)). Whereas the office's managerial functions were repeated-to "decide on the internal organization of the Commission, ensuring that it acts consistently, efficiently and as a collegiate body" (EUR-Lex, 2002, Art. 217/1, 2007, Art. 9D/6(b))its political function has again grown vague. Therefore, although the demand to provide political agendasetting leadership has been essential to the Commission presidency throughout the process of European integration, the Lisbon Treaty still leaves room for multiple interpretations. 
The European Union is a polycentric system in which the Commission presidency holds the key intermediary position. Its incumbent is the only actor who participates equally in all three major arenas of policy formulation and decision-making as a member and first representative of the College of Commissioners, the European Council (even without voting rights), and through regular participation in plenary sessions of the European Parliament. No other individual political position can so self-evidently move across of all these three arenas. Therefore, it is not only essential for the incumbent to invest in consensus-building to meet his/her leadership potential; the office itself plays a central mediating role in the EU's inter-institutional framework (Cini, 2005, p. 7; Endo, 1999, p. 37; Peterson, 1999, p. 48). In other words, convincing member states and the Parliament's political groups of a certain agenda is both process and substance of successful leadership by Commission presidents. Although the treaties only indirectly provide for the mediative function (EUR-Lex, 2007, Art. 9D/1 + 9D/6 (a-c), 9B/2), the institutional structure shows that such leadership is at the core of the office (Endo, 1999, p. 37).

To help build compromises in the three different EU arenas, the president does not only need to express to other players what needs to be done but, more importantly, how it can be done. For this the president requires administrative-procedural and technocratic expertise to provide solutions at the legal-procedural level (Curtin, 2009, pp. 61, 99). The Lisbon Treaty, and the Nice Treaty before it, vests the president with the previously mentioned power over the Commission (EUR-Lex, 2007, Art. 9 D/6 (b)). However, administrative-procedural expertise does not just consist of effectively running an organization. It also includes perspectives on (re-)organizing administrative processes, thus attempting "to expand institutional resources [and] lifting institutional constraints" (Endo, 1999, p. 36; Peterson, 1999, p. 48). As a consequence, political mediation and technocratic expertise are two sides of the same coin. The first refers to the political sphere of initiating, negotiating and agreeing on what needs to be done politically. The latter points to the procedural side of this process, namely offering insight into how political initiation and agreement can be realized and implemented properly. In terms of leadership functions, these two demands can be subsumed under mediativeinstitutional leadership.

Finally, the president aims to (re-)present the Commission and the union more broadly. In this sense, s/he does not only represent the Commission and defend its influence and prestige but also serves as promoter of the 'community interest' both in the European and international public spheres. The Lisbon Treaty states more explicitly than the Nice Treaty that the Commission "shall ensure the Union's external representation" (EUR-Lex, 2007, 9 D/1); however, it remains vague on the matter of the presidency. The link between the Commission president and the European public spheres is still less strong than that between national leaders and their constituencies. Yet the incumbent is nonetheless accountable and responsive to the European public, especially following the 2014 European elections. As occupant of one of the highest European public offices, the Commission president relies on a positive image in the public sphere to steer and maintain political support (Tömmel, 2008, p. 140; Wille, 2013 , pp. 89,91 ). This function, of not only representing the Commission technically, but also creating public attention and support for the Commission's agenda and European issues more broadly, can be identified as public leadership.

\subsection{Institutional Resources and Constraints}

While the functions of an office are linked to its legalprocedural structure, the presidency's institutional resources and constraints to provide political leadership confirm the mixed picture presented above. Since the Rome Treaty, the appointment of Commission presidents has undergone enormous changes: From nominating the president by the Council in 1957 to electing him/her in the European parliamentary elections through top-candidates of the European political groups in 2014. While it was the member states' prerogative to appoint the College of Commissioners and its president unanimously (EUR-Lex, 1957, Art. 158), the Maastricht Treaty (1992) enhanced the role of the European Parliament as a consultative organ in the nomination process (Endo, 1999, p. 70; Nugent, 2001, p. 62). Since 1995, the Treaty also provides the president with limited influence on the nomination of commissioners (Nasshoven, 2011, p. 87). Meanwhile, the president-elect and the nominated College have become subject to a vote of approval by the Parliament before being officially appointed by the Council (EURLex, 1992, Art. 158: 2), which is why the Commission's investiture procedure had also been aligned to the European elections (Nugent, 2001, p. 45).

However, both the Nice and Lisbon Treaties changed this procedure in profound fashion. First, the European Council aims at nominating the president by a qualified majority instead of unanimity (EUR-Lex, 2007, Art. 17). This change offers more dynamism in choosing a president, as the selection cannot be blocked by a member state anymore, which most likely avoids 'lowestcommon denominator' nominations (Nasshoven, 2011, pp. 89-90). Second, the candidate needs to be elected by the Parliament before the selection of the College, representing the Parliament's political majority after the latest European elections (Wille, 2013, p. 63). Third, the president-elect and the nominated College are subject to hearings and finally a parliamentary vote. In addition, the Parliament has a veto right against the nominated 
College, and in 2013 decided to nominate their own topcandidates (Spitzenkandidaten) for the Commission presidency in the 2014 elections (Kassim, 2016, pp. 2-3). On the one part, this increased reliance on the European Parliament aims at expanding the political legitimacy of the Commission president and increasing his/her political influence and public visibility. On the other, this new dependence on party-political directions also poses a threat to the president's political independence and the Commission's function of representing the Union's common interest (Kassim, 2016, p. 5). In addition, although the president might have been elected by a majority of MEPs, s/he cannot necessarily count on this majority during his/her term since faction or coalition compliance do not exist in the EP. Finally, the concurrent political dependence on two powerful but antagonistic institutions, the Parliament and the Council, poses a crucial challenge to actually provide leadership at all.

Moreover, the Lisbon Treaty introduced two further high-level EU positions, which weaken the Commission president's agenda-setting potential, mediation powers and his/her public visibility (Christiansen, 2012, pp. 230, 237; Tömmel, 2015, p. 9). For one part, there is the permanent president of the European Council who, by "chairing and driving forward [the Council's] work" (EUR-Lex, 2007, Art. $9 \mathrm{~B} / 6(\mathrm{a})$ ) potentially limits the Commission president's prerogative of mediating in the Council, promoting the Union's general interest, and thus also reducing the Commission president's agendasetting influence (Curtin, 2009, p. 77; Dinan, 2013, pp. 1258, 1262-1263). Before 2009, the Commission president developed the Council's agenda together with the rotating Council presidency and thus had a much more direct access to member states (Endo, 1999, p. 60). In addition, due to the Council's rotation, the Commission president also had a generally more pronounced overview over current European affairs than individual heads of government and state. However, the permanent Council president now holds this key position of direct access to the rotating presidency, and this constrains the Commission president's opportunities to influence Council proceedings (Tömmel, 2015, pp. 13, 18-19, 21-22). For example, the close relationship that existed between Commission president Jacques Delors, German chancellor Helmut Kohl and French president François Mitterrand during the 1980s, would be much more difficult to obtain today with the permanent Council president intervening between the two sides (Dinan, 2013, p. 1266; Endo, 1999, pp. 62-63). For another, the High Representative of the Common Foreign and Security Policy (CFSP) who by "ensur[ing] the consistency of the Union's external action[s]" (EUR-Lex, 2007, Art. 9E/4) also diminishes the president's international visibility even if $s /$ he is not formally assigned to the CFSP (Barber, 2010, p. 59).

Inside the Commission, the main constraint arises from the requirement that each member state still del- egates one commissioner (EUR-Lex, 1957, Art. 157). The Lisbon Treaty aimed at diminishing the number of commissioners "corresponding to two thirds of the number of Member States" (EUR-Lex, 2007, Art. 9 D/5). However, despite this, the European Council in May 2013 decided to continue the former practice until the accession of the $30^{\text {th }}$ member state (European Council, 2013). Thus the Commission president is confronted with commissioners of 27 different nationalities and political backgrounds (Döring, 2007, pp. 224-225; Egeberg, 2006, p. 11; Smith, 2003, p. 142). The president is provided with the right to influence the selection process of commissioners and distributes portfolios among them. Nonetheless conflicting relationships may arise concerning policies, competences, portfolios, and personalities (Döring, 2007, p. 224; Endo, 1999, pp. 78, 81; Spence, 2006, p. 55). Yet the principle of one commissioner per member state also increases the legitimacy of the Commission to provide European-wide policy solutions. Moreover, the president may still benefit from the increase in commissioners, since a larger number may prevent any single commissioner from building his/her own power base inside the Commission.

Another ambivalent intra-institutional constraint potentially emerges from the College's principle of collegiality (RoP [1963]/2000, Art. 1). Whereas this principle once represented a key source of legitimacy for the Commission's actions, it has become increasingly difficult to apply it to an ever-expanding organization. The latest treaty revisions clearly enhanced the president's role (EUR-Lex, 2007, Art. 9D/6(a)); still, the College of Commissioners represents a group of politically highprofile and quite independent individuals (Spence, 2006, pp. 38-39; Stevens \& Stevens, 2001, p. 222). Even with a stronger hierarchy of seven vice presidents among them, as introduced by Jean-Claude Juncker in 2014, the president can neither rely on a formal coalition agreement, nor does s/he decide independently on the composition of the College or make use of a stronger voting power than the other commissioners (Cini, 2005, p. 2; Kassim, 2016, p. 7; Kassim et al., 2013, p. 156). However, apart from these institutional constraints, the Lisbon Treaty also provided the office with some legal-procedural resources, especially within the Commission, through the requirement to once again adopt its own Rules of Procedure (RoP) (EUR-Lex, 2007, Art. 249; European Commission, 2010). The term "political guidance" did disappear from the Lisbon Treaty, but was reintroduced in the amended RoP of 2010. These rules permit the president to "lay down the political guidelines within which the Commission shall exercise its functions..., [and] steer the work of the Commission in order to ensure it is carried out" (European Commission, 2010, Art. 3 (1)). It can, however, be debated whether it is more significant to refer to "political guidance" in the Treaty or in the Commission's internal Rules of Procedure. 
While the Rome Treaty already permitted the president to convene, share, and set the College's agenda, today the rules are also formulated that only the secretary-general and the president's head of cabinet are allowed to attend College meetings, privileging the president vis-à-vis other commissioners (Endo, 1999, p. 40; Kassim et al., 2013, p. 156, 2016, p. 8; Nugent, 2001, p. 68; European Commision, 2010, Art. 10 (1)). This exemption equally applies to the modification of propositions, the restructuring of the agenda, and the signing of minutes (European Commission, 2010, Art. 6 (5); Art. $11(2))$. In addition, the president is not only vested with the right to distribute Commission portfolios during the investiture procedure. $\mathrm{S} / \mathrm{he}$ can also reshuffle them later during the term, demanding resignations by commissioners (except for the High Representative), as well as creating and controlling portfolios added to his/her own responsibilities (EUR-Lex, 2002, Art. 217 (4), 2007, Art. 9 D/6 c; European Commission, 2010, Art. 3/6, Art. 22).

Finally, two further resources emerge from the president's cabinet and the Commission's SecretariatGeneral. Since the early days of the Commission, the president has always had more advisers and personal staff than other commissioners, allowing for the opportunity to influence and modify the Commission's agenda at the Cabinet's working level (Kassim et al., 2013, p. 156; Stevens \& Stevens, 2001, p. 235). In addition, the RoPs' latest amendments have officially elevated the Secretariat-General from an executive secretary of the Commission to a rather "political body" working for the president providing him/her with substantial upstreaming power inside the Commission (Endo, 1999, p. 41; Kassim, 2013a, pp. 14-15; Kassim et al., 2016, pp. 7-8; European Commission, 2010, Art. 20 (1)). Consequently, while many of the institutional resources have been available to the president since the first Commission took office, only relatively few, though essential, resources have been added since the latest treaty amendments were made.

\subsection{The Leadership Potential of the Commission President}

The analysis of the Lisbon Treaty and certain sections of the Commission's Rules of Procedure demonstrated that neither the political functions of the Commission presidency nor its legal-procedural resources were substantially altered or strengthened by the latest revisions. Despite introducing a paragraph dedicated to the office, the Lisbon Treaty remains relatively vague as to the office's political leadership functions. Moreover, the creation of new EU positions substantially challenges the Commission president's potential for agenda-setting, inter-institutional mediation and public visibility at the European level. All in all, the Treaty hardly made the office more powerful in its political functions. The same applies to the office's legal-procedural re- sources. Although the president now officially determines the internal organization of the Commission, mainly through the Commission's Rules of Procedure, many of these "new" rights have been used since the very first Commission took office. In fact, apart from the closer, though important, alignment of the Secretariat-General to the power resources of the Commission presidency, the Lisbon Treaty did not substantially extend the office's institutional powers. It rather aligned them with its increased constraints regarding the Commission's expansion (Christiansen, 2012, p. 237; Curtin, 2009, p. 74; Tömmel, 2008, pp. 120-121).

In conclusion, the formalization of the office, based mainly on managerial-organizational changes inside the Commission, does not automatically imply more political leadership on the part of the Commission president. The institutional structure is still a mixed picture for the Commission president. The balance of resources and constraints has remained relatively stable over the course of European integration with generally weak institutional opportunities to fulfill the leadership demands, especially in the inter-institutional realm. This means that increased resources inside the Commission, have been relatively neutralized by increased institutional constraints both in- and outside the Commission. To extend Kassim's words, it was not just "Hallstein and Delors [who] relied on personal standing and authority" and their own strategic choices to tackle the office's institutional constraints and provide political leadership; Barroso's power and those of present and future presidents-despite latest treaty revisions-remains all in all still more reliant on personal capacities than "the constitutional strengthening of the office" (Kassim, 2013a, p. 16; Kassim et al., 2013, p. 174).

\section{The Leadership Performance of José Barroso}

To observe these personal challenges of balancing strong political demands with weak institutional powers, it is worth analyzing the public performances of Commission presidents. The literature on EU politicization suggests that increased authority of supranational institutions due to treaty revisions leads to an increase of media attention in the European public spheres on said institutions (De Wilde \& Zürn, 2012, pp. 149-150; Rauh, 2014, pp. 2, 4; Rauh \& Zürn, 2014, pp. 125-126; Zürn, 2013, pp. 13, 15, 19)..$^{1}$ Following this line of argument, and hypothesizing that the Lisbon Treaty would have strengthened the presidency (in contrast to the findings of the previous section), public attention on, for example, José Barroso, Commission president be-

\footnotetext{
${ }^{1}$ Politicization means the transfer of a decision/institution into the realm of politics, increasing public attention on it, in terms of increased salience and polarization, as well as the mobilization of new resources to match the increased attention (Rauh \& Zürn, 2014, pp. 125-126).
} 
tween 2004-14, would have most likely increased after the coming-into-force of said treaty in 2009.

To verify this assumption, a theory of candidatemedia agenda convergence is applied to study the public performance of José Barroso. In addition, a cursory comparison to his predecessor Jacques Delors, Commission president between 1985-95, who is often regarded as the pinnacle of leadership success for Commission presidents, is drawn to further strengthen the argument (Brummer, 2014; Hayes, 2008, pp. 135-136, 143, 2010, pp. 595-596; Kassim et al., 2013; Tömmel, 2013). In doing so, Barroso's and Delors' speeches, and the topics they addressed, are compared with the issues they were associated with in newspaper articles. The strength of this overlap between the presidents' topics and the issues they were related to in the media is then understood as an indicator of their capacity to provide public leadership at the European level. This assumes that the more concentrated the manner in which the issues were addressed, the more likely they were to be covered by the media (Hayes, 2008, pp. 135-136, 143, 2010, pp. 595-596). The British Financial Times (FT), one of the prime newspapers which covers EU-related topics for a Pan-European readership, serves as exemplary media source. ${ }^{2}$ The following section systematically compares the main topics of Barroso's 588 speeches and Delors' 265 speeches with the 174 FT articles covering Barroso between 2004-14, and the 312 articles reporting on Delors between 1985-95. ${ }^{3}$

\subsection{The Public Impact of Presidential Speeches}

The distribution of speeches and newspaper articles already provides some contradictory results as both follow different cyclic developments (Figure 1). Barroso started with a lower number of speeches at the beginning of each term (on average 30.5 speeches p.a. between 2004-5 and 2009-10), reaching the highest frequency of speeches in mid-term (compare 75 and 82 speeches in 2008 and 2011 respectively). The end of each term in office (2009 and 2014) is then characterized again by lower numbers of speeches, 40 and 45 respectively. ${ }^{4}$ However, the newspaper articles invert

\footnotetext{
${ }^{3}$ The speeches were retrieved from the Archives of the European Commission in Brussels (Delors), and the website of the European Commission (Barroso) (European Commission, 2014a, 2014b). The dataset of speeches consists of full speeches given at public or semi-public conferences, opening speeches and keynote addresses, detailed or closing remarks and interventions. The FT articles were retrieved from the FT digital archive and the LexisNexis database. Both databases were systematically consulted for articles in which the term "Delors" or "Barroso" was mentioned in either the headline or as a subtitle for the respective period.

4 The low number of speeches in 2006 (22) can be interpreted as an outlier due to a low retrieval from the European Commission database for this year.
}

${ }^{2}$ For a similar methodological approach see Kurpas et al. (2008).

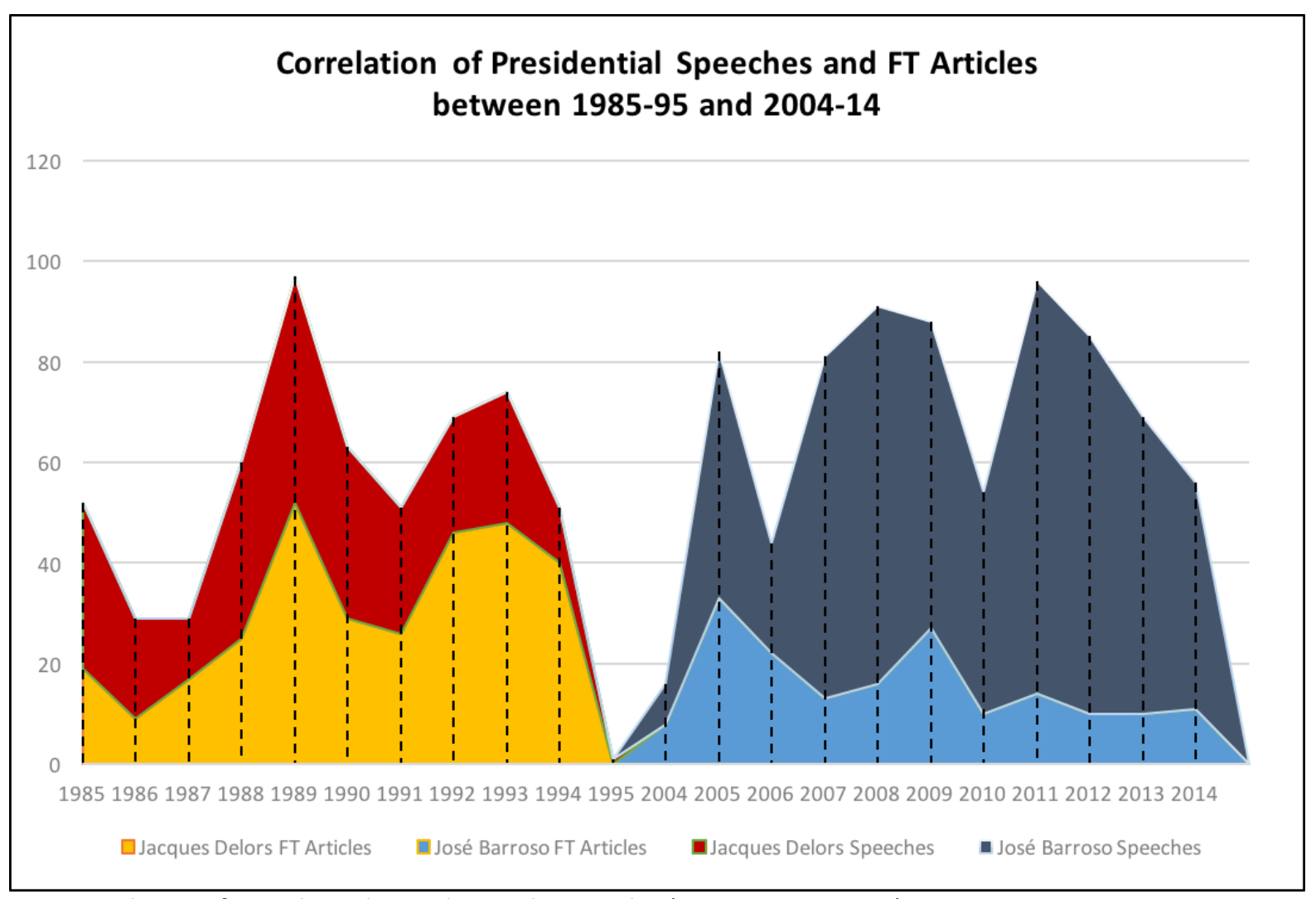

Figure 1. Correlation of presidential speeches and FT articles (1985-95, 2004-14). 
this pattern. Although the FT increased its coverage of Barroso during 2004 and 2005, with a total of 41 articles, it did not follow Barroso's strong outreach strategy in the years 2007 and 2008; it in fact decreased its coverage even further compared to 2005. Only during Barroso's reappointment in 2009 did the FT again increase its reporting, reaching its second highest point of coverage with 27 articles. Although Barroso gave most speeches of his incumbency in 2011/12, the FT's reporting on Barroso decreased even further, thus remaining lower than during his first term (with 11 articles on average during 2010-14). Despite slight increases in coverage in 2008/9 and 2011, Barroso was thus generally not able to draw public media attention to his political agenda by increasing his public outreach efforts. In fact, during his second term, media coverage was even lower than in the first term (114 and 60 articles respectively), although he had delivered more speeches in his second term (262 and 326 speeches respectively).

Comparing these results to the public media performance of Jacques Delors, it becomes even more apparent that Barroso was largely unsuccessful in steering and focusing public attention onto himself despite increased public exposure (Figure 1). Across 1985-95, Jacques Delors gave about 265 speeches, making a particularly 'strong outreach push' at the beginning of each of his terms, which were covered by the Financial Times with an overall amount of 312 articles. As the graphs reveal, the FT's coverage was not only higher in absolute terms than Delors' outreach, but also nearly symmetrically covered Delors' public exposures. The theory of candidate-media agenda convergence argues that "public opinion [intends] to encourage convergence [between] [politicians'] and media agendas", since both tend to "alight on similar sets of topics [due to their, H.M.]...unwilling[ness] to focus on issues that lack public salience" (Hayes, 2010, pp. 595-596). As a result, "media appear generally responsive to themes emphasized by [politicians]" except when, for example, media do not acknowledge the authority of the politician in a particular area or disagree with the importance of issues set by the politician (Hayes, 2010). In accordance with this argument, Delors' results do not only confirm that a close symmetrical coverage of speeches and articles is possible. It also indicates a successful outreach strategy, thereby showing that Delors' success was not just caused by a positive context of his incumbency, but equally included his own strategies and leadership capacity. As for politicization theories of international organizations, the disparity between the higher FT coverage of fewer of Barroso's speeches across his first term and more of his speeches gaining lower FT coverage in his second term also indicates that the Lisbon Treaty may indeed not have strengthened the office's political and public authority, e.g. due to the creation of new EU high level positions.

\subsection{The Public Convergence of Presidential Speeches}

The second step evaluates to what extent Barroso and Delors were able to link their main political agendas to their presidencies in the public media. In his 588 speeches, José Barroso addressed eight main topics in his central political agenda, which were apparent throughout his two terms to varying degrees of intensity. ${ }^{5}$ The first topic was growth, jobs, and innovation, in which Barroso sought to steer the political debate towards new financial investments in order to stimulate European-wide economic growth, employment and technological innovation (Cini, 2005, pp. 5-6; Kassim et al., 2016, p. 13; Kurpas, Grøn, \& Kaczyński, 2008, p. 19). With $21 \%$, this main topic was the leading single issue of his political agenda throughout his presidency. The second essential point of Barroso's agenda was Europe's future and renewal capturing $14 \%$ of his main topics, while his third most important topic was globalization, which amounted to $12 \%$. Fourth, the topic of European values, culture, citizens and civil society was another one of his central concerns (14\%) (Cini, 2005, pp. 5-6). Addressed in a total of $61 \%$ in the category of main topics these four issues were central to his political agenda and of continuous importance throughout his presidency.

These agenda items were accompanied by four additional main issues that were, characterized by greater fluctuation, due to a strong influence by internal/external political events at the European level. These four topics were, first, the Euro area including the institutions of Ecofin, EFSF and ESM (11\%). Here, Barroso addressed most notably the financial governance of the Eurozone, which became particularly important in 2009, 2010 and 2011 at the height of the European financial debt crisis and the economic and financial situation in Greece and other southern European states. Second, this topic was accompanied by more general elaborations about the EU single market and economic governance (9\%), in which Barroso argued for a deeper economic and financial integration of the European Union. The third main topic was the

\footnotetext{
${ }^{5}$ The content analysis of Barroso's and Delors' speeches and respective FT articles was conducted with the qualitative data analysis software MAXQDA. One speech/article may address more than one topic, but each topic was only coded once in a speech/article. The coding of speeches/articles followed an exploratory approach, guided by a set of four higher-ranking categories, which had been developed alongside the frequency, and as such the significance of topics. Speeches: (1) Delors'/Barroso's main topics/political agenda, (2) general EC/EU issues, (3) EC/EU internal/external events, and (4) EC/EU policies. Articles: (1) Delors'/Barroso's main topics, (2) general EC/EU issues, (3) EC/EU policies, (4) FT coverage of Delors/Barroso apart from their agenda. For the purpose of this paper only the categories concerning the presidents' main topics are being analyzed.
} 
EU's external cooperation and its partnerships (11\%). Here, again, questions of globalization and international economic governance played an important role. Finally, Barroso also focused on climate change, environment and sustainable development (8\%). However, this topic decreased in significance after the 2009 UN climate summit in Copenhagen and the outbreak of the European sovereign debt crisis (Kassim et al., 2016, p. 12; Schout \& Buirma, 2014, p. 3).

Comparing these results to those of Delors' political agenda, a huge divide becomes apparent. First, although Delors had also addressed around seven issues in the category of main topics over the course of his presidency (completion of the single market (14\%), technological cooperation and innovation (10\%), financial and monetary cooperation (21\%), institutional functioning of the Community (16\%), social dimension and social cohesion (18\%), closer political cooperation and political union (10\%), and finally external cooperation $(11 \%))$, he addressed not more than five central topics at the same time. This is in line with studies of public opinion, which concluded that public spheres hardly focus on more than five issues at one time (Jones \& Baumgartner, 2004, p. 2; Princen, 2009, p. 20). In fact, Delors developed a strong thematic and dynamic overlap among his main topics, strategically interlocking each topic with the former one, the socalled method of engrenage. These topics ranged from the completion of the single market (Single European Act, 1986/7) to stronger social cohesion (Community Charter of Fundamental Social Rights, 1988/9), and finally closer financial and monetary cooperation (Economic and Monetary Union, 1992) (Drake, 2000, p. 14).

Taking into account Delors' success in setting Europe's political agenda during his presidency (Endo, 1999), the distribution of Barroso's political agenda indicates that, with eight broad main topics, Barroso's agenda was continuously overloaded and thus in part diluted when compared to his predecessor. Second, the development of Barroso's main topics suggests a two-pronged agenda strategy. On the one hand, he focused on his first four main topics in a way that was relatively independent of actual political developments. These four topics were characterized by strong generalizations, ones easily applicable to a broad range of political occasions. On the other, he followed political developments at European level closely in an adhoc reactive mode, e.g. climate change or the EU financial system (Hodson, 2013, p. 303; Schout \& Buirma, 2014, p. 6). However, while Barroso's four constant and four fluctuating main topics remained somewhat separate and detached from each other, it can be assumed that it was potentially more difficult for Barroso's audiences to actually identify his political priorities and his main political agenda. The analysis of the Financial Times' reporting on Barroso's main topics confirms this assumption.
The newspaper reported most notably on Barroso's comments about the Euro/EMU/Ecofin/EFSF/ESM and the EU's financial governance (at $26 \%$ in the coverage of Barroso's main topics). In addition, the FT paid particular attention to Barroso when he announced and discussed matters of the EU single market/economic governance, as well as his central topic of growth/jobs/innovation/Lisbon Agenda (with 22\% and $18 \%$ respectively). The FT also reported frequently on two of Barroso's other main topics (namely EU external cooperation/partnerships/development as well as climate change/environment/ecologic governance with $17 \%$ and $12 \%$ respectively). This seems at first to be a good result in terms of a convergence between agenda and public coverage. Yet the reporting of the Financial Times nearly inverted the priority setting of Barroso's agenda. Barroso put a strong focus on economic growth, the EU's future, European values and globalization (which made up to $61 \%$ of his main topics), less often addressing the more fluctuating main topics of the Eurozone as well as financial and economic governance, EU external cooperation and climate change (with only $39 \%$ in the overall distribution of main topics). Conversely, however, the Financial Times covered these latter fluctuating topics far more often (with $77 \%$ in the overall coverage of Barroso's main topics) than his four stable topics (23\%) (Figure 2). As these findings illustrate, despite a general overlap between Barroso's agenda-setting and FT coverage, the different priority settings and issue attention between José Barroso and the Financial Times are obvious.

In contrast, the FT followed Delors' agenda and priority setting much more closely (Figure 3). While Delors focused most notably on the topic of closer financial and monetary cooperation, the FT also covered this topic in the majority of its articles on Delors' main topics $(39 \%)$, thereby even exceeding the frequency with which Delors had addressed this issue $(21 \%$ of main topics). This indicates that Delors' agenda items had become politicized to a significant degree (Drake, 2000, p. 51). Delors' second, third and fourth main topics (completion of single market, social dimension and institutional functioning) were also covered by the newspaper with largely the same priority setting (16\%, 14\% and $10 \%$ respectively). Finally, Delors' three other main topics (technological cooperation, political cooperation and closer political cooperation and political union) were also covered roughly in accordance with his priority setting $(6 \%, 10 \%$ and $5 \%$ respectively). Hence, a high thematic convergence and partially strong politicization can be observed between the main topics of Delors' speeches and the topics he was associated with in the FT.

In summary, three major conclusions derive from analyzing the public convergence of presidential speeches. First, a general overlap between the topics addressed in the speeches and the topics Barroso was 


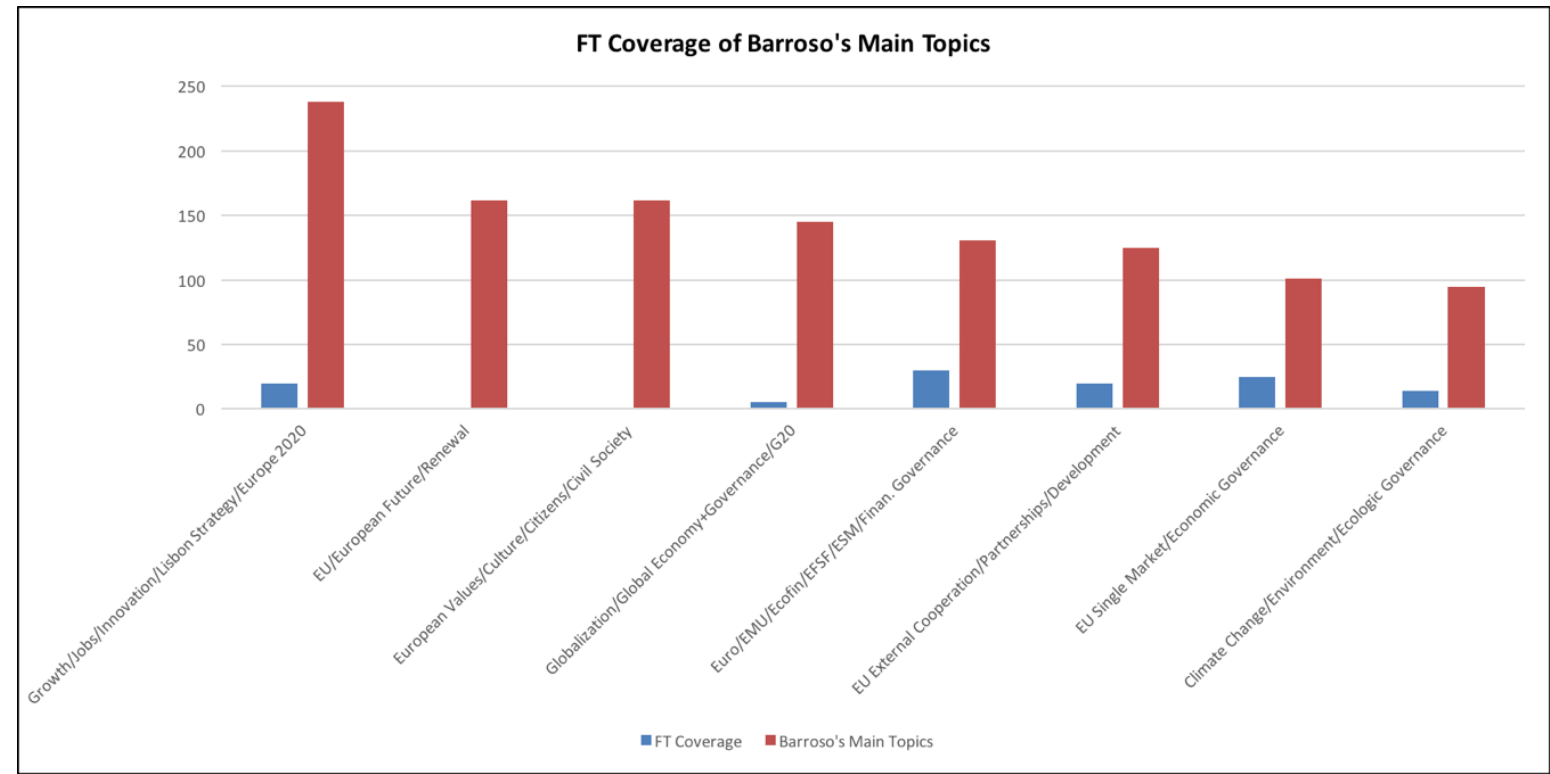

Figure 2. FT coverage of Barroso's main topics.

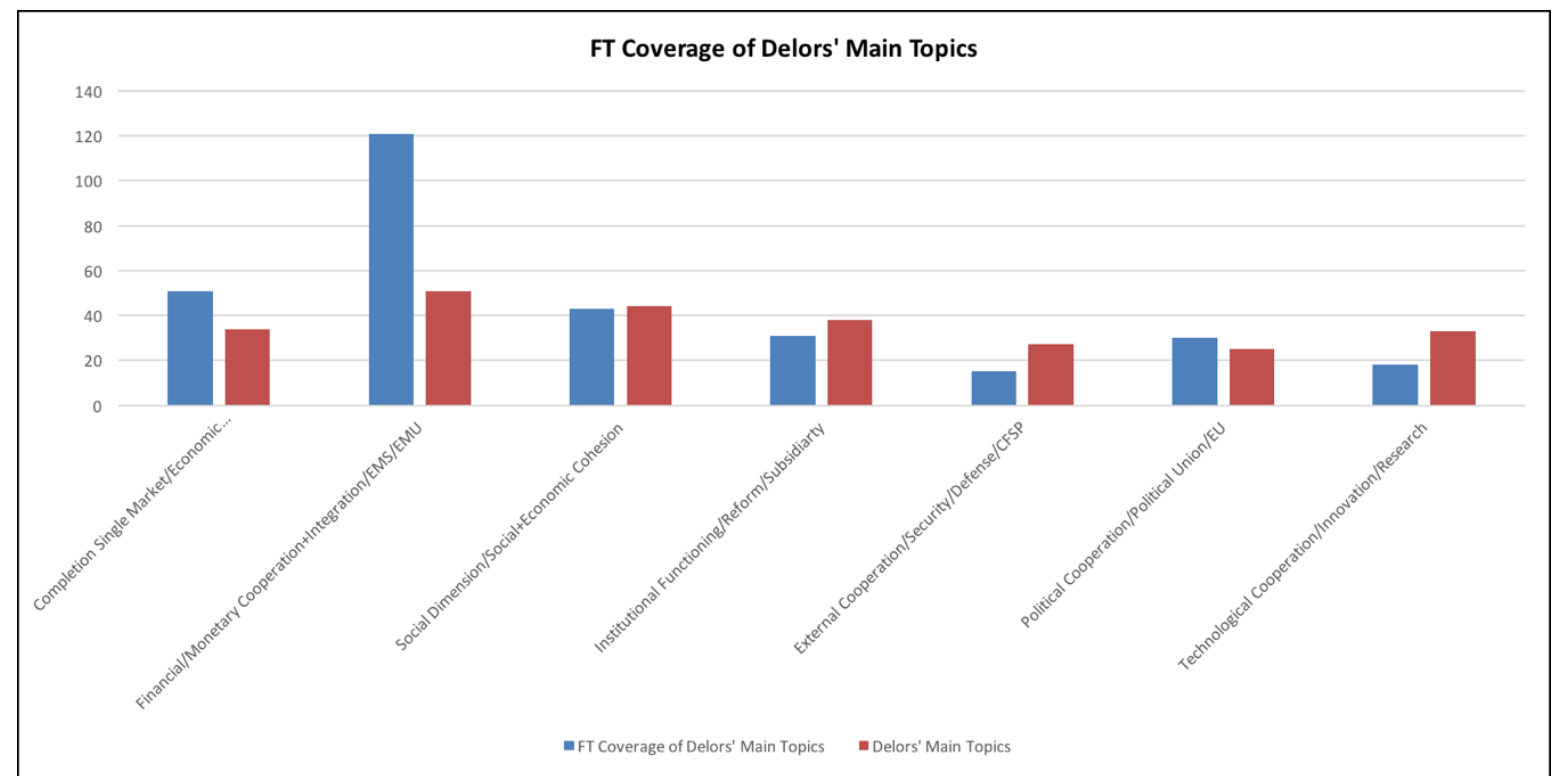

Figure 3. FT coverage of Delors' main topics.

associated with in the Financial Times can be identified, though the newspaper featured them at a very different frequency and focus. Of his eight main topics, only two were frequently covered by the newspaper. Since the other main topics such as the EU's future hardly constituted a substantive agenda, they were covered much less frequently by the newspaper. Although Commission presidents usually represent the Commission's collective mission and the union's common interest, and therefore seek to address European issues in more general terms, rhetorical vagueness or commonplaces potentially threaten an incumbent's seriousness and may thus have an adverse effect on his/her media coverage. In contrast to Delors' strong convergence of thematic coverage, the Financial Times inverted the priority setting of Barroso's main topics.
As a result, Barroso largely failed in presenting and disseminating his political agenda to the public spheres.

Second, and taking cursorily into account the context of Barroso's presidency, it becomes apparent that even when Barroso's media coverage was relatively high, it did not necessarily relate to his own contributions, but rather coincided with key events at the European level. This becomes particularly evident in the FT's coverage of Barroso in the years 2004/5, 2008, 2009 and 2011, where his outreach efforts coincided with central events at the European level such as the Commission's (re-)appointment, the international financial crisis or the European sovereign debt crisis.

Third, the sharp decrease in the FT's coverage from Barroso's first to his second term (although he had given more speeches) substantiates the assumption that 
after 2009 Barroso's public attention had been potentially decreased by other EU offices. This indicates that the Lisbon Treaty has hardly strengthened the political powers and authority of the Commission presidency at the European level.

\section{Conclusion: What Kind of Leadership Prospect?}

The goal of this paper was twofold. First, it aimed to analyze the institutional role of the Commission presidency and its legal-procedural powers before and after the Treaty of Lisbon came into force in an effort to evaluate the office's political leadership potential. Second, it sought to explore the public performance of the Commission president José Barroso in comparison to his successful predecessor Jacques Delors in order to further substantiate the article's argument. In this regard, Barroso's and Delors' public performances were analyzed by comparing the frequency and main topics of their speeches with their respective coverage in the newspaper Financial Times. Only one newspaper and one other incumbent, Jacques Delors, were used to illustrate Barroso's public performance and future analysis therefore needs further research on other newspapers and presidents. Nonetheless, the study allows for two main conclusions which also clarify the office's leadership prospect.

First, with regard to theories of politicization in global governance, the FT's sharply decreased coverage of José Barroso during his second term illustrates that the Lisbon Treaty may not have increased the political role of the Commission president at the supranational level. If the Treaty had significantly strengthened the office, more frequent coverage of the president would have been likely especially since Barroso dramatically increased his public exposure. However, the opposite was the case. In particular, the creation of two new EU offices potentially contributed to Barroso's decreased media coverage. Second, while supranational institutions can only make a significant impact on European policy-making if they use "their formal powers and competences to a maximum", this study demonstrated that this 'maximum' still largely depends on the individual leading these institutions and his/her strategic choices, which have to be redefined by each incumbent (Tömmel, 2014, p. 28). Barroso was thus far from offering "entrepreneurial or pre-eminent" leadership when it came to his public performance (Brummer, 2014, p. 343; Kassim, 2013a, pp. 16, 18).

In conclusion, since the Lisbon Treaty hardly increased the office's institutional powers especially in the EU's inter-institutional realm, the prospect for the Commission presidency indicates that the exercise of its leadership functions still strongly relies on the incumbent's personal leadership capacities. In the words of Barber: "What the [Lisbon] treaty does not contain,...is that vital ingredient for success-political will- power" (Barber, 2010, p. 66). The strengthening of managerial-organizational functions alone does not automatically imply that actual political leadership is or can be provided. Otherwise Barroso's public performance would most likely have been stronger than that of Delors'. The predominant reliance on the dispositions of individuals in supranational institutions indicates a strong vulnerability as to whether they function effectively or not. The creation of supranational institutions with relatively weak legal-procedural resources may indeed be in the interest of member states, since it safeguards their national sovereignty and control over major political developments at the European level. Yet it also hinders the institution's actual effectiveness. Weak institutional powers (structure) do not indicate less, but paradoxically more dependence on the relatively unpredictable variable of individual capacities (agency) to successfully execute an office's political leadership demands. Hence a strong reliance on individuals counterweighs the central aim of institutionbuilding, namely a stable exercise of power and the provision of continuity and predictability in decisionmaking processes.

\section{Acknowledgements}

The author would like to thank the Archives of the European Commission in Brussels for granting generous access to the collection of speeches of the European Commission presidents. An earlier draft was presented at the $7^{\text {th }}$ Pan-European conference of the ECPR Standing Group on European Union in The Hague, 5-7 June 2014. Here the author would like to thank the panel participants George Ross, Ingeborg Tömmel and Amy Verdun for their comments. She is also grateful to three anonymous referees who offered helpful suggestions for improving the work.

\section{Conflict of Interests}

The author declares no conflict of interest.

\section{References}

Ahlquist, J. S., \& Levi, M. (2011). Leadership: What it means, what it does, and what we want to know about it. Annual Review of Political Science, 14, 1-24.

Barber, T. (2010). The appointments of Herman van Rompuy and Catherine Ashton. Journal of Common Market Studies, 48, 55-67.

Brummer, K. (2014). Die Führungsstile von Präsidenten der Europäischen Kommission. Zeitschrift für Politik, 3(61), 327-345.

Byman, D. L., \& Pollack, K. M. (2001). Let us now praise great men. Bringing the Statesmen back in. International Security, 25(4), 107-146.

Christiansen, T. (2012). The European Union after the 
Lisbon Treaty: An elusive 'institutional balance'? In A. Biondi, P. Eeckhout, \& S. Ripley (Eds.), EU Law after Lisbon (pp. 228-247). Oxford: Oxford University Press.

Cini, M. (1996). The European Commission. Leadership, organisation and culture in the EU administration. Manchester and New York: Manchester University Press.

Cini, M. (2005). Pragmatism prevails: Barroso's European Commission. London: Chatham House.

Curtin, D. (2009). Executive power of the European Union. Law, practices, and the living Constitution. Oxford: Oxford University Press.

De Wilde, P., \& Zürn, M. (2012). Can the politicization of European integration be reversed? Journal of Common Market Studies, 50(1), 137-153.

Dinan, D. (2013). The post-Lisbon European Council Presidency: An interim assessment. West European Politics, 36(6), 1256-1273.

Döring, H. (2007). The composition of the College of Commissioners. Patterns of delegation. European Union Politics, 8(2), 207-228.

Drake, H. (2000). Jacques Delors. Perspectives on a European leader. London and New York: Routledge.

Egeberg, M. (2006). Executive politics as usual: Role Behaviour and conflict dimensions in the College of European Commissioners. Journal of European Public Policy, 13(1), 1-15.

Elgie, R. (1995). Political leadership in liberal democracies. Basingstoke: Palgrave Macmillan.

Elgie, R. (2015). Studying political leadership. Foundations and contending accounts. Basingstoke: Palgrave Macmillan.

Endo, K. (1999). The presidency of the European Commission under Jacques Delors. The Politics of shared leadership. Oxford: Macmillan Press.

EUR-Lex. (1957, March 25). Treaty establishing the European Economic Community and connected documents (TEEC) (11957E/TXT). Luxembourg: Publishing Services of the European Communities.

EUR-Lex. (1992, February 7). Treaty on European Union, together with the complete text of the Treaty establishing the European Community (TEU-M) (C191). Brussels: Official Journal of the European Communities.

EUR-Lex. (2002, December 24). Treaty of Nice amending the Treaty on European Union, the Treaties establishing the European Communities and certain related acts (TEU-N) (C 325/113). Brussels: Official Journal of the European Union.

EUR-Lex. (2007, December 17). Treaty of Lisbon amending the Treaty on European Union and the Treaty establishing the European Community (TEU-L) (C 306/16). Brussels: Official Journal of the European Union.

EUR-Lex. (2007, December 17). Treaty on the Functioning of the European Union consolidated version after the Treaty of Lisbon (TFEU) (C 326/49). Brussels: Official Journal of the European Union.

European Commission. (2010, February 24). Commission Decision amending its Rules of Procedure (L 55/60). Brussels: Official Journal of the European Union.

European Commission. (2014a, October 1). Barroso's speeches 2004-2009. Retrieved from http://ec.euro pa.eu/archives/commission_20042009/president/ar chives/2009/index_en.htm

European Commission. (2014b, October 1). Barroso's speeches 2010-14. Retrieved from http://ec.euro pa.eu/archives/commission_20102014/president/ne ws/archives/2012/09/index_en.htm\#top

European Council. (2013, May 22). The European Council decides on the number of members of the European Commission (EUCO 119/13). Brussels: Official Journal of the European Union.

Greenstein, F. I. (1992). Can personality and politics be studied systematically? Political Psychology, 13(1), 105-128.

Hayes, D. (2008). Does the messenger matter? Candidate-media agenda convergence and its effects. POlitical Research Quarterly, 61(1), 134-146.

Hayes, D. (2010). The dynamics of agenda convergence and the paradox of competitiveness in presidential campaign. Political Research Quarterly, 63(3), 594611.

Helms, L. (2005). Presidents, Prime ministers, and Chancellors: Executive leadership in Western Democracies. Basingstoke: Palgrave Macmillan.

Helms, L. (2016). Introduction: Leadership questions in transnational European governance. European Political Science, 1-13. doi:10.1057/eps.2015.113

Hodson, D. (2013). The little engine that wouldn't: Supranational entrepreneurship and the Barroso Commission. Journal of European Integration, 35(5), 301-314.

Jones, B. D., \& Baumgartner, F. R. (2004). Representation and agenda setting. The Policy Studies Journal, 32(1), 1-24.

Kassim, H. (2013a). A new model presidency: Leadership of the European Commission under Barroso (20042014). Berlin: PEU.

Kassim, H. (2013b). The presidents and the presidency of the European Commission. In E. Jones, A. Menon, \& S. Weatherill (Eds.), The Oxford handbook of the European Union. Oxford: Oxford University Press.

Kassim, H. (2016). What's new? A first appraisal of the Juncker Commission. European Political Science, 120. doi:10.1057/eps.2015.116

Kassim, H., Peterson, J., Bauer, M. W., Connolly, S., Dehousse, R., Hooghe, L., \& Thompson, A. (2013). The European Commission of the twenty-first century. Oxford: Oxford University Press.

Kassim, H., Connolly, S., Dehousse, R., Rozenberg, O., \& Bendjaballah, S. (2016). Managing the house: The presidency, agenda control and policy activism in the 
European Commission. Journal of European Public Policy, 1-22. doi: 10.1080/13501763.2016.1154590

Keohane, N. O. (2010). Thinking about leadership. Princeton: Princeton University Press.

Kurpas, S., Grøn, C., \& Kaczyński, P. M. (2008). The European Commission after enlargement: Does more add up to less? Brussels: Center for European Policy Studies.

Nasshoven, Y. M. (2011). The appointment of the President of the European Commission: Patterns in choosing the head of Europe's executive (1. ed.). BadenBaden: Nomos.

Nugent, N. (2001). The European Commission (2. ed.). Basingstoke: Palgrave.

Peterson, J. (1999). The Santer Era: The European Commission in normative, historical and theoretical perspective. Journal of European Public Policy, 6(1), 4665.

Pollack, M. A. (1997). Delegation, agency, and agenda setting in the European Community. International Organization, 51(1), 99-134.

Princen, S. (2009). Agenda-setting in the European Union. Basingstoke: Palgrave Macmillan.

Rauh, C. (2014). Communicating supranational governance? The salience of EU affairs in the German Bundestag, 1991-2013. European Union Politics, 16(1), 116-138.

Rauh, C., \& Zürn, M. (2014). Zur Politisierung der EU in der Krise. In M. Heidenreich (Ed.), Krise der europäischen Vergesellschaftung? Soziologische Perspektiven (pp. 121-145). Wiesbaden: Springer Verlag.

Ross, G. (1995). Jaques Delors and European integration. Cambridge: Polity Press.
Schout, A., \& Buirma, T. (2014). Ten years of Barroso's presidency: Passive or smooth operator? Internationale Spectator, 68(2), 30-35.

Smith, A. (2003). Why European Commissioners matter. Journal of Common Market Studies, 41(1), 137-155.

Spence, D. (2006). The President, the college and the cabinets. In D. Spence \& G. Edwards (Eds.), The European Commission (3 ed.). London: John Harper Publishing.

Stevens, A., \& Stevens, H. (2001). Brussels bureaucrats? The administration of the European Union. Basingstoke: Palgrave Macmillan.

Tömmel, I. (2008). Das politische System der EU (3 ed.). Munich: Oldenbourg.

Tömmel, I. (2013). The Presidents of the European Commission: Transactional or transforming leaders? Journal of Common Market Studies, 51(4), 789-805.

Tömmel, I. (2014). The European Union: What it is and how it works. Basingstoke: Palgrave Macmillan.

Tömmel, I. (2015). The 'permanent' President of the European Council: Intergovernmental or supranational leadership? Paper presented at the conference "Political Leadership in the EU", 20 November, University of Osnabrück.

Wille, A. (2013). The normalization of the European Commission: Politics and bureaucracy in the EU Executive. Oxford: Oxford University Press.

Zürn, M. (2013). Politisierung als Konzept der Internationalen Beziehungen. In M. Zürn \& M. Ecker-Ehrhardt (Eds.), Die Politisierung der Weltpolitik. Umkämpfte internationale Institutionen (pp. 7-35). Berlin: Suhrkamp.

\section{About the Author}

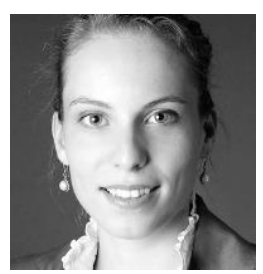

Henriette Müller is a political scientist who recently completed her PhD thesis at Humboldt University Berlin (HU). Her research interests are comparative politics, government and governance studies with a particular focus on political leadership. Müller is currently a research fellow at the NYUAD Institute of the New York University in Abu Dhabi where she conducts a comparative analysis of the influence of political leadership on economic growth, exploring the dynamic of this relationship at the example of countries from the Gulf region, Western Europe and South East Asia. 